\title{
Impact of Presowing Seed Treatments, Tempera- ture and Seed Coats on Germination of Velvet Bundleflower
}

\author{
M.R. HAFERKAMP, D.C. KISSOCK, AND R.D. WEBSTER
}

\begin{abstract}
Seeds with both smooth and rough, apparently scarified, seed coats occur in harvested samples of velvet bundleflower (Desmanthus velutinus Scheele.). To determine the degree of scarification, germination responses of rough and smooth seeds were investigated at 4 night/day temperature regimes, $5 / 15^{\circ} \mathrm{C}, 10 / 20^{\circ} \mathrm{C}$, $15 / 25^{\circ} \mathrm{C}$, and $20 / 30^{\circ} \mathrm{C}$ with a 12 -hour photoperiod during the high temperature and with 3 seed treatments, cutting, acid scarification and hot water soak. Rough seed coats appear to be caused by peeling of the cuticular layer on the seed surface. Moisture was imbibed more rapidly by smooth seeds, and total germination of smooth seeds was $31 \%$ without treatment, 4 times greater than rough seed germination. Treatments increased germination of smooth seeds two- to four- fold and rough seeds over 10-fold. After treatment, rough seeds germinated significantly $(P<.05)$ better than smooth seeds at all temperature regimes except $5 / 15^{\circ} \mathrm{C}$. Cut and scarified seeds generally germinated more rapidly than watertreated seeds, but total germination was similar for all treatments at warmer temperatures. Germination was only $31 \%$ at $5 / 15^{\circ} \mathrm{C}$.
\end{abstract}

Velvet bundleflower (Desmanthus velutinus Scheele.), a spreading somewhat decumbent perennial forb, grows mostly on calcarous and limestone soils of central, south, and west Texas (Rechenthin 1972). The forage is favored by goats, sheep, and deer, and seeds may be eaten by quail and other birds. Seed samples of one accession being evaluated for use in rangeland seedings and wildlife habitat plantings by the Soil Conservation Service contained seeds with smooth and rough appearing seed coats. This variation in seed coat, observed in seed lots harvested in 1977, 1979, and 1980, suggested a potential for differences in moisture imbibition and subsequent germination, since the rough appearance of the seed coats could be evidence of seed coat scarification. Hard, impervious seed coats are barriers to moisture and gas movement, as well as, a restriction to seedling development in many legumes (Crocker and Barton 1957, Latting 1961, Villiers 1972).

These studies were designed with the objectives to: (1) evaluate the effects of seed coat characteristics on moisture imbibition and seed germination and (2) evaluate the effects of temperature and presowing seed treatments on seed germination.

\section{Materials and Methods}

Seed of PMT-2406 velvet bundlcflower was obtained from the USDA Plant Materials Center, Soil Conservation Service, Knox

\footnotetext{
Authors were assistant professor and graduate research assistants, Texas Agr. Exp. Sta. (Dept. of Range Science), Texas A\&M Univ., College Station, Texas 77843. Present addresses are Eastetn Oregon Agr. Res. Center-Squaw Butte Sta., Burns, Oregon 97720; Brown and Associates, College Station, Texas 77843; and Research School of Biological Sciences, Taxonomic Unit, the Australian National Univ., P.O. Box 4, Canberra, A.C.T., Australia 2600.

The authors gratefully acknowledge the USDA Soil Conservation Service, Plant Materials Center, Knox City, Texas, for providing seeds used in the study, Miss Edie Oliver for laboratory assistance, and Mr. Don Shelton for assistance in the statistical analysis.

Approved for publication by the Director, Texas Agr. Exp. Sta., as Tech. Article No. 17847.

Manuscript received November 12,1982
}

City, Texas, in 1979. These seeds were harvested in 1977 with a combine and subsequently run through a scalper and three-screen seed cleaner. After harvest seeds were stored in a warehouse for 3 or 4 months and then they were stored at $60^{\circ} \mathrm{F}$ and $40 \%$ relative humidity. Once we received the sample, seeds were stored in cloth sacks at room temperature. Germination trials were conducted with 3-year old seed, sorted by hand, so only uniformly large sized, fully developed and undamaged rough and smooth seeds were used.

Seeds were treated by cutting the seed coat with a razor blade (Latting 1961, Martin et al. 1975), immersion of seeds in hot water $\left(80^{\circ} \mathrm{C}\right)$ for 3 minutes (Halls et al. 1970, Latting 1961), and acid scarification by immersion in concentrated sulfuric acid $\left(\mathrm{H}_{2} \mathrm{SO}_{4}\right)$ for 17 minutes (Latting 1961). Acid scarification was conducted in test tubes with acid just covering the seeds. After treatment excess acid was poured from the sample, and the remaining acid was washed from the seeds with distilled water. Washing with a large amount of water reduced the heating that occurs with the dilution of the acid.

Germination trials were conducted in a controlled environmental chamber. Night/day temperatures were $5 / 15^{\circ} \mathrm{C}, 10 / 20^{\circ} \mathrm{C}$, $15 / 25^{\circ} \mathrm{C}$, or $20 / 30^{\circ} \mathrm{C}$ with 12 -hour photoperiods during the high temperature. All experiments were conducted in a light regime of $237 \mathrm{vEm}^{-1} \mathrm{sec}^{-1}$ photosynthetic active solar radiation. One trial was conducted at each temperature regime, and 3 replications of 50 seeds per seed treatment were arranged in a randomized complete block design.

A sample of 50 seeds per dish was dusted with fungicide N[(trichloro-methyl)thio]-4-cyclohene-1,2-dicarboximide and imbibed on 2 pieces of filter paper in a $100-\mathrm{mm}$ diameter petri dish. The paper was supported by a 5-mm thick piece of polyurethane foam with a cotton wick in the center (Haferkamp et al. 1977). Filter paper was kept moist with sterile distilled water $(\mathrm{pH} 6)$. One piece of moistened filter paper was placed beneath the dish cover to increase moisture availability.

Response to treatment was evaluated by counting germinated seeds daily for 14 days. Germination criteria were based on the Association of Official Seed Analysts (Crosier 1970) definition of germination, i.e., the seed embryo must develop essential structures to produce a normal plant in favorable conditions. Normal germination was assumed when at least one cotyledon was exposed and the radical was at least $5 \mathrm{~mm}$ long.

Seed moisture content after $0,2,4,8$, and 12 hours of imbibition was determined gravimetrically on samples of smooth and rough seeds imbibed in the $15 / 25^{\circ} \mathrm{C}$ regime. Following imbibition seeds were blotted dry, weighed, oven-dried for 48 hours at $105^{\circ} \mathrm{C}$ and reweighed.

Electron microscope photographs were also taken of untreated seeds to permit closer observation of seed coats. These seeds were mounted on aluminum studs, coated with gold palladium in a vacuum evaporator, and examined with a scanning electron microscope. 

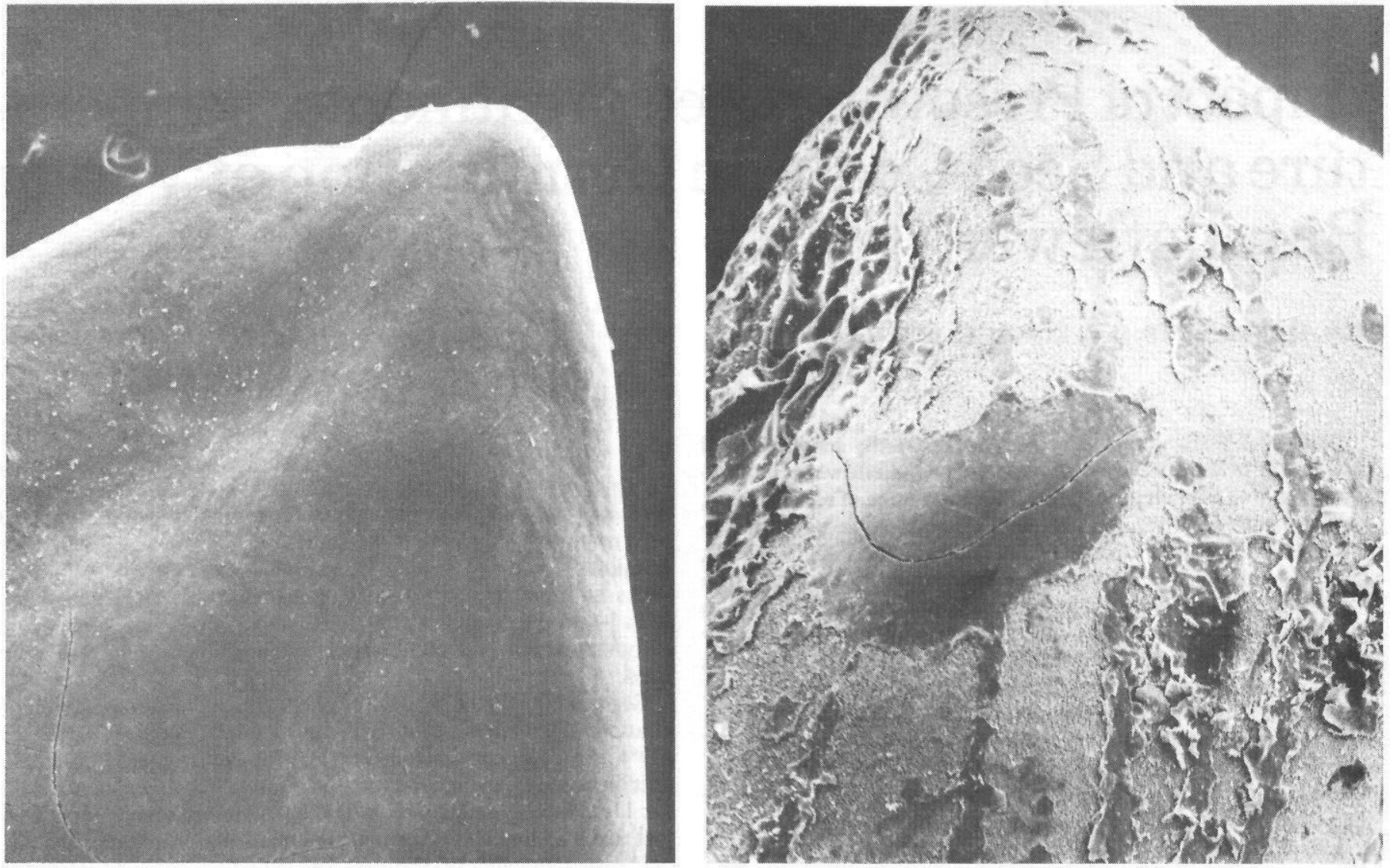

Fig. 1.' Seed coat of smooth (left) and rough (right) velvet bundleflower seeds, magnification $60 X$.
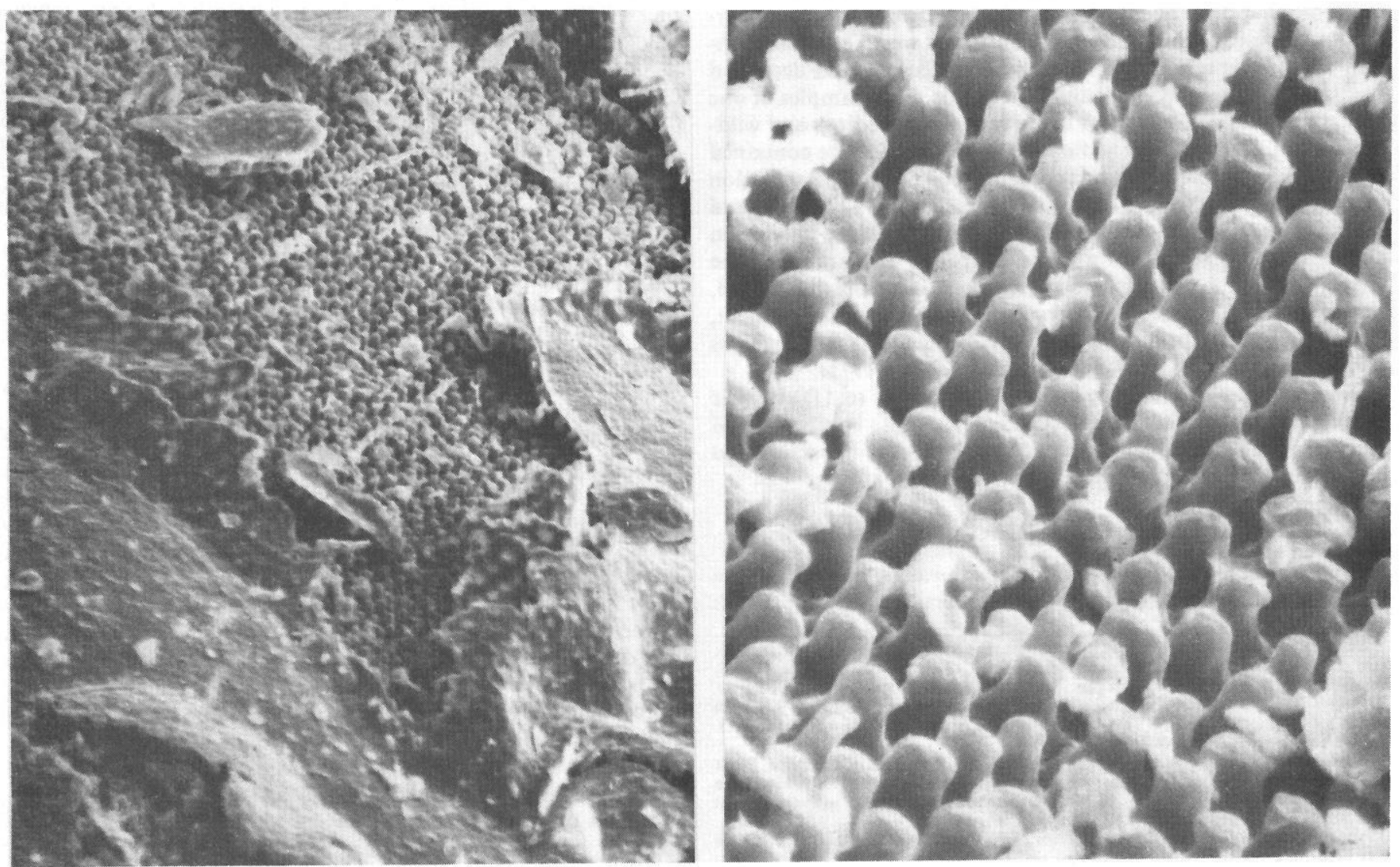

Fig. 2. Rough seed coat with a peeling cuticular layer, magnification $400 X$ (left), and caps of macrosclerid cells, magnification $2000 X$ (right). 
statistical analyses were conducted with the ANOVA procedure to determine if significant differences $(P<0.05)$ in germination existed between types of seed coats and among presowing treatments within temperature regimes. Means were separated using Duncan's multiple range test. Counts were transformed prior to analysis using the following relationship:

$$
X^{\prime}=\sqrt{(n+1 / 2)} \arcsin \quad \sqrt{\frac{1+3 / 8}{n+3 / 4}}
$$

where the proportion (germinated seeds/total number of seeds) is f/n (Zarr 1974). Untransformed data are presented in the text.

\section{Results and Discussion}

\section{Electron Micrographs}

The rough appearance of velvet bundleflower seeds is caused by peeling of the seed surface (Fig. 1 and 2). Projections on the rough seeds appear to be caps of macrosclerid cells of the pallisade layer or Malpghian cells as reported by Hamly (1932). The impermeable region of the seed coat of sweet clòver Meliloius alba Desr. is composed of a layer of tightly appressed suberin caps (Hamly. 1932). He reported that the cuticle and subcuticular layers could be removed without improving moisture imbibition, but when caps were removed or breaks were formed in the layer, moisture imbibition could occur.

\section{Moisture Imbibition}

Deterioration of the cuticle and subcuticular layers of velvet bundleflower seed did not improve moisture imbibition. Smooth seeds imbibed moisture more rapidly during the initial 12 hours than the rough seeds (Fig. 3). The cuticle is apparently permeable, and when intact enhances imbibition. When the cuticle begins to separate from the seed and an air space is formed, imbibition may be reduced. The possibility of moisture imbibition occurring through other openings in the seed coat exists, but this was not examined.

\section{Seed Germination}

\section{Untreated Seeds}

Smooth seeds consistently germinated as well or better than rough seeds (Fig. 4). Highest total germination of rough and

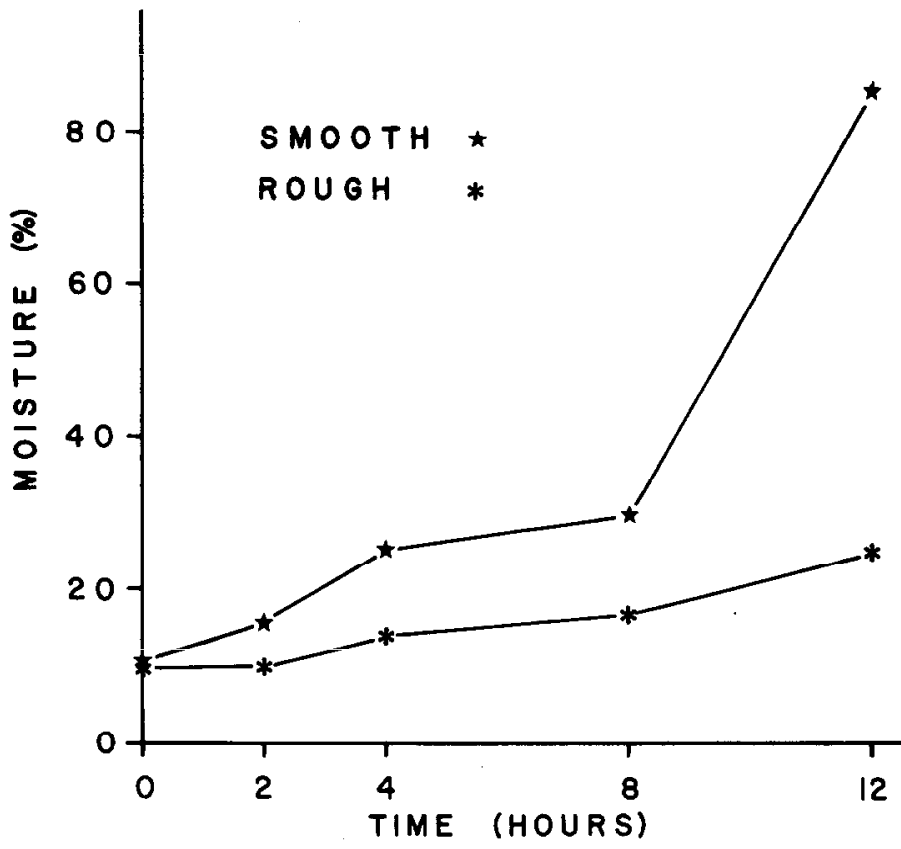

Fig. 3. Moisture content (\% of dry weight) of rough and smooth velvet bundleflower seeds imbibed at $15 / 25^{\circ}$ C for 12 hours. Moisture contents were significantly different ( $\mathrm{p} 0.05$ ) between seed types at each sampling time.

smooth seeds was $9 \%$ and $31 \%$, respectively. Seed germination was poorest at $5 / 15^{\circ} \mathrm{C}$ for both seed types. Differences between seed types were small and nonsignificant $(P>0.05)$ at $5 / 15^{\circ} \mathrm{C}$ and $10 / 20^{\circ} \mathrm{C}$, but smooth seeds germinated 2 to 4 times better $(P<0.05)$ at $15 / 25^{\circ} \mathrm{C}$ and $20 / 30^{\circ} \mathrm{C}$.

Physiological activity was apparent by day $\mathrm{I}$ at $20 / 30^{\circ} \mathrm{C}$ and day 2 at $10 / 20^{\circ} \mathrm{C}$ and $15 / 25^{\circ} \mathrm{C}$ when approximately 2 to $5 \%$ of the seeds had either one cotyledon or a short radicie exposed (data not shown). Activity was not apparent until day 6 to 8 at $5 / 15^{\circ} \mathrm{C}$. Germination rate was most rapid at $15 / 25^{\circ} \mathrm{C}$ and $20 / 30^{\circ} \mathrm{C}$, intermediate at $10 / 20^{\circ} \mathrm{C}$ and slowest at $5 / 15^{\circ} \mathrm{C}$.
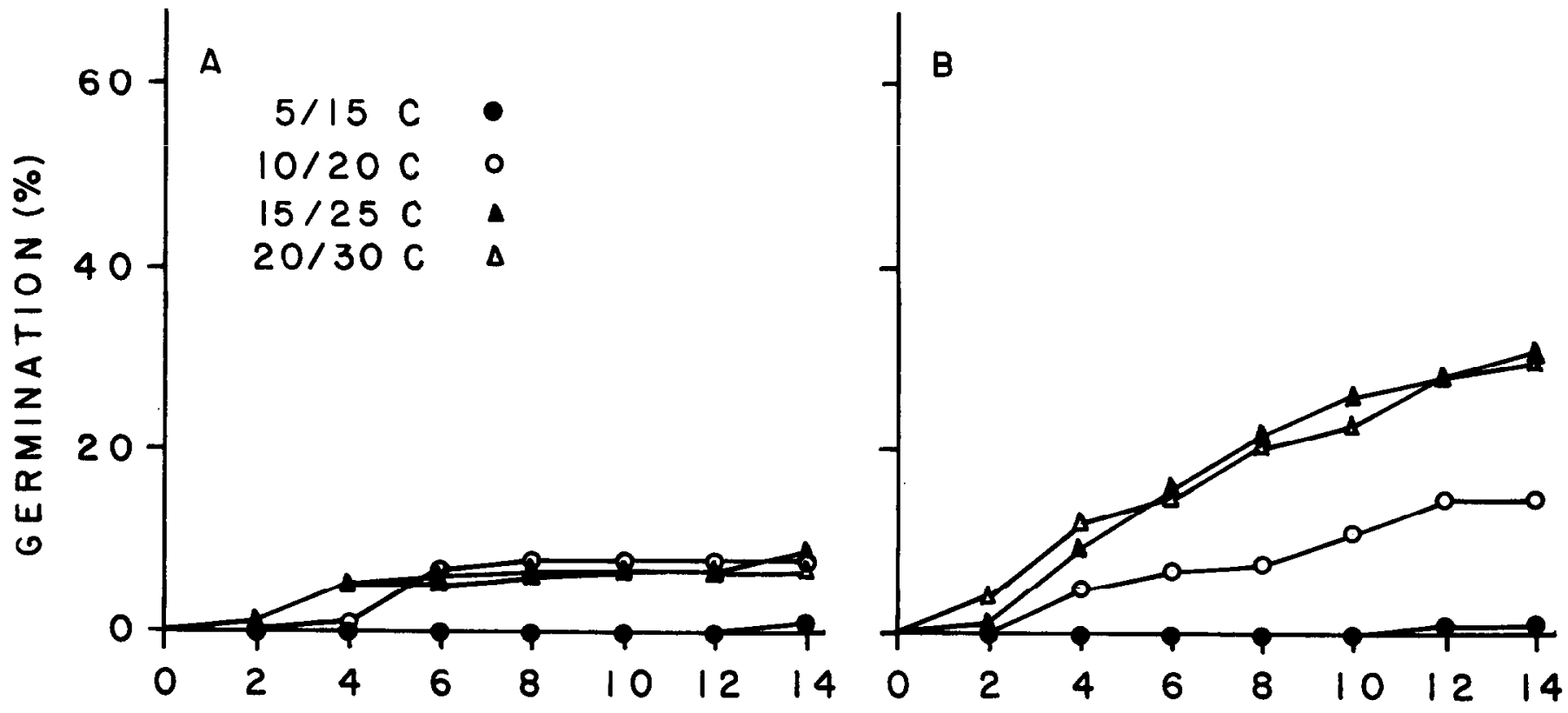

TIME (DAYS)

Fig. 4. Cumulative germination of rough $(A)$ and smooth $(B)$ velvet bundleflower seeds in four temperature regimes. 


\section{Treated Seeds}

Seed treatments generally improved germination of rough and smooth seeds at all temperature regimes (Fig. 5). Rough seeds

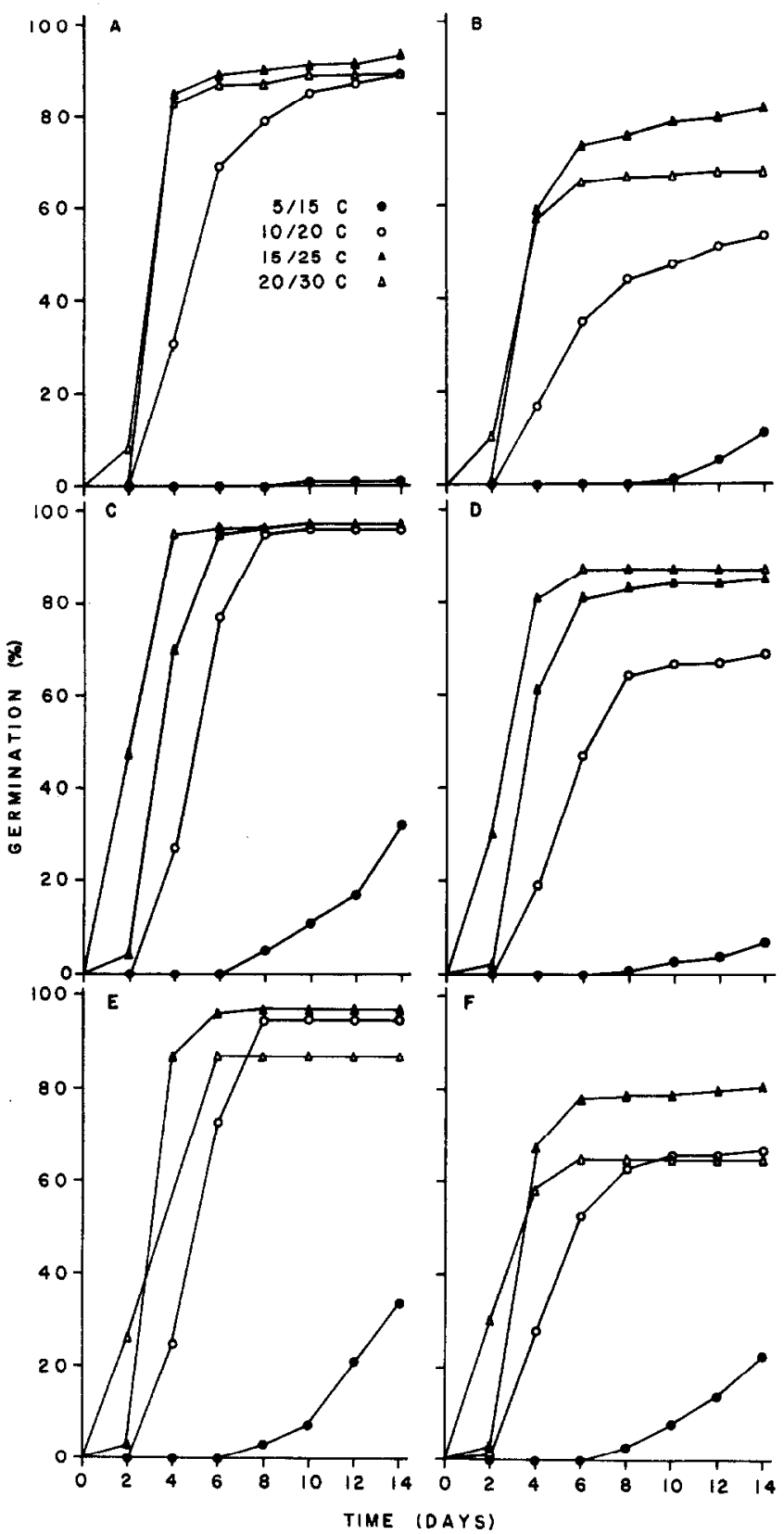

Fig. 5. Cumulative germination of hot water soaked rough $(A)$ and smooth $(B)$, cut rough (C) and smooth (D), and acid scarified rough (E) and smooth $(F)$ velvet bundleflower seeds in 4 temperature regimes.

germinated significantly $(P<0.05)$ better than smooth seeds at all temperature regimes except $5 / 15^{\circ} \mathrm{C}$. Germination of rough seeds averaged 73,93 , and $90 \%$ on day 6 at $10 / 20^{\circ} \mathrm{C}, 15 / 25^{\circ} \mathrm{C}$ and $20 / 30^{\circ} \mathrm{C}$, respectively. Over $87 \%$ of these rough seeds had germinated by day 14 . Approximately 45,77 , and $72 \%$ of the smooth seeds had germinated by day 6 at $10 / 20^{\circ} \mathrm{C}, 15 / 25^{\circ} \mathrm{C}$, and $20 / 30^{\circ} \mathrm{C}$, respectively. Over $80 \%$ of the treated seeds had germinated after 14 days at $15 / 25^{\circ} \mathrm{C}$, but less than $70 \%$ of the water soaked and acid scarified seeds germinated at $20 / 30^{\circ} \mathrm{C}$. The decrease was not explained by the study.

Cut and acid scarified seeds generally germinated more rapidly than the water treated seeds (Fig. 5). However, total germination of water treated seeds was similar to that of cut and scarified seeds at $15 / 25^{\circ} \mathrm{C}$ and $20 / 30^{\circ} \mathrm{C}$. Hot water was apparently not as effective as cutting or scarification in improving imbibition and subsequent germination.

At $5 / 15^{\circ} \mathrm{C}$ germination of all seeds was relatively poor (Fig. 5). Cut and scarified rough seeds germinated best at the low temperature regime with over $30 \%$ germination. Germination consistently began sooner at the warmest temperature regime, and during the initial 2 to 4 days seeds germinated most rapidly at $15 / 25^{\circ} \mathrm{C}$ and $20 / 30^{\circ} \mathrm{C}$. Germination was usually apparent by day 2 at $10 / 20^{\circ} \mathrm{C}$, and the maximum rate of germination occurred during days 2 to 8 . Total germination was attained 2 to 4 days earlier at $15 / 25^{\circ} \mathrm{C}$ and $20 / 30^{\circ} \mathrm{C}$ than at $10 / 20^{\circ} \mathrm{C}$.

\section{Summary and Conclusion}

Rough seed coats appeared to be caused by peeling of the cuticular layer on the seed surface. Disturbance of the cuticular layer did not appear to be due to natural causes. Established stands of velvet bundleflower were examined at Knox City, Texas, in fall 1980 , and researchers found only smooth seeds in pods. Rough seeds were found in harvested seed lots in 1977, 1979 and 1980, suggesting disturbance of the cuticular layer may have occurred during harvesting or post-harvesting drying. Slight abrasion during harvesting and handling may have disturbed the seed coats. Peeling may also be initiated with post-harvest drying since smooth seed coats were observed to become rough when smooth seeds were imbibed for less than 12 hours and then dried for 48 hours at $105^{\circ} \mathrm{C}$.

Researchers utilizing velvet bundleflower seeds should be aware that rough and smooth seeds imbibe and germinate at different rates. Differences, however, can be reduced by applying presowing seed treatments such as cutting and acid scarification or soaking in hot water. Data suggest cutting was an effective treatment, and this treatment would probably be more practical for field plantings if a method of mechanically scarifying bulk seed lots was available. Planting mixtures of untreated smooth and rough seeds should provide seeds that germinate rapidly and seeds that germinate later with subsequent moisture. Germination of rough seeds, however, may be improved through natural weathering processes occurring in the soil.

Data also suggest germination of rough and smooth seeds was low at $5 / 15^{\circ} \mathrm{C}$ and began sooner, proceeded more rapidly and total germination was generally higher in warmer temperature regimes. Planting prior to moist periods when the warmer temperatures occur could enhance germination in field plantings. If, however, natural, weathering was found effective in reducing the amount of hard seed, then earlier plantings might suffice as effective means to enhance germination.

\section{Literature Cited}

Crocker, W., and L.V. Barton. 1957. Physiology of seeds. Chronica Botanica Co. Waltham, Mass.

Crosier, W.E. (ed.). 1970. Rules for testing seeds; Proc. of the Ass. of Off. Seed Analysts. Vol. 60, No. 2.

Haferkamp, M.R., G.L. Jordan, and K. Matsuda. 1977. Presowing seed treatments, seed coats, and metabolic activity of Lehmann lovegrass seeds. Agron. J. 69:527-530.

Halls, L.K., C.J. Perkins, and J. Turk. 1970. Seeded legumes reproduce poorly on cutover longleaf pinelands. USDA Forest Service. Southern Forest Exp. Sta., Research Note SO-105:1-1.

Hamly, D.H. 1932. Softening of the seeds of Melilotus alba. Bot. Gaz. 93:345-375.

Latting, J. 1961. The bilogy of Desmanthus illionoensis. Ecology 42:487-493. Martin, R.E., R.L. Miller, and C.T. Cushwa. 1975. Germination response of legume seeds subjected to moist and dry heat. Ecology 56:1441-1445.

Rechenthin, C.A. 1972. Native flowers of Texas. USDA, Soil Conservation Service. Temple, Texas.

Villiers, T.A. 1972. Seed dormancy. In:T.T. Kozlowski (ed.). Seed biology. Academic Press, Inc., New York. p. 219-281.

Zarr, J.H. 1974. Biostatistical analysis. Prentice Hall, Inc. Englewood Cliff, New Jersey. 